\title{
Assessing the impact of extreme rainfall events on the geomorphic stability of a conceptual rehabilitated landform in the Northern Territory of Australia
}

\author{
J.B.C. Lowry Department of the Environment, Water, Heritage and the Arts, Australia \\ K.G. Evans Department of the Environment, Water, Heritage and the Arts, Australia \\ T.J. Coulthard Department of Geography, The University of Hull, United Kingdom
}

G.R. Hancock Faculty of Science and Information Technology, The University of Newcastle, Australia

D.R. Moliere Bureau of Meteorology, Department of the Environment, Water, Heritage and the Arts, Australia

\begin{abstract}
The Ranger uranium mine located in the Northern Territory of Australia is the largest producer of uranium oxide in Australia. It is currently envisaged that the mine will cease production and commence rehabilitation after 2020. The mine lease is located in the catchment of Magela Creek and is surrounded by the worldheritage listed Kakadu National Park. The Supervising Scientist Division of the Commonwealth Department of the Environment, Water, Heritage and the Arts undertakes an independent physical, chemical and biological monitoring programme in the Magela catchment to check for any impacts, including stream sediment loads, by mine-related activities. During late February and early March 2007, a period of exceptionally heavy rainfall occurred throughout the entire Magela Creek system as a result of a monsoon trough that extended across the top end of the Northern Territory. In what has been categorised as a greater than 1-in-100 year storm event, total rainfall over the three day period between 27 February and 2 March 2007 at Jabiru airport near Ranger was $785 \mathrm{~mm}$, the largest three day rainfall that has been recorded in this region.

The general extent of sediment transport and flooding associated with this storm highlighted the need to have an understanding of the possible impacts of extreme rainfall events on the erosion of the proposed rehabilitated mine landform and subsequent sediment export to Magela Creek. An understanding of these effects can be gained through landform evolution modelling (LEM). One such model is Cellular Automaton Evolutionary Slope And River (CAESAR). In contrast to LEM packages such as Siberia that use data that has been averaged, CAESAR uses an hourly rainfall record and has the capacity to simulate the effects of discrete rainfall events on landform stability. Simulations were conducted using a digital elevation model (DEM) of the largest catchment of a proposed rehabilitated mine site using the Jabiru hourly rainfall recorded over a 21 year period. For the purposes of the simulation, the tailings dam catchment was attributed with the surface characteristics of waste rock. Data collected for the greater than 1-in-100 year rainfall event in 2007 were inserted into this rainfall record after an initial ten year simulation period, to allow the CAESAR model to simulate the impact of the storm event, and the model run for a further 11 years. The simulation showed a pulse of sediment moving out of the catchment immediately after the storm event and identified a denudation rate of $5.6 \mathrm{mmy}^{-1}$ during the 2007 rainfall year time series. In contrast, previous studies in the region, using various methods produced a range of denudation rates for waste rock of -2-7 $\mathrm{mmy}^{-1}$ with a median of $0.04 \mathrm{mmy}^{-1}$. Further research is required to identify the potential impact of extreme rainfall events on other possible surface treatment types in a catchment setting.
\end{abstract}

\section{Introduction}

Mining operations can be the cause of pollution of downstream waterways through the erosion of disturbed areas like waste rock dumps and tailings containment structures. This may give rise to public and stakeholder concerns about the impacts of mine sites, including the degradation of water resources. Within Australia, 
governments have legislated to control the impacts of mining through setting standards for water quality and conducting site inspections. By understanding the properties of overburden material, particularly erodibility and particle size distribution, erosion during the operating and subsequent decommissioning and rehabilitation phases can be managed. Rehabilitation planning and landform design need to consider landform shape and surface treatments that reduce erosion and encapsulate contaminants. This is particularly pertinent in the wet-dry tropics of northern Australia, which experience an annual average rainfall of $1480 \mathrm{~mm}$ (Bureau of Meteorology, 1999), most of which falls in the wet season between October and April. A further concern is the impact of an increased frequency of extreme weather events that may result from climate change.

A number of models have been used to evaluate erosion and simulate post mining landscape stability (Riley, 1994; Evans and Loch, 1996; Evans, 2000; Loch et al., 2000). These models include the water erosion prediction programme (WEPP) (Laflen et al., 1991; Flanagan and Livingston, 1995), universal soil loss equation (USLE), modified universal soil loss equation (MUSLE), revised universal soil loss equation (RUSLE) (Onstad and Foster, 1975; Wischmeier and Smith, 1978; Renard et al., 1994), and Siberia (Willgoose et al., 1989).

Evans (2000) proposed that landform shape can be optimised using an iterative process involving mathematical erosion simulation models. That is, an engineer firstly designs a landform shape based on earthwork quantities, drainage requirements and rehabilitation criteria. The design shape is then input into a three-dimensional landform simulation model in the form of a DEM with proposed surface treatments such as ripping, vegetation and/or rock mulching and drainage structures. Erosion can be simulated for various time periods and water quality changes caused by simulated sediment export rates assessed against agreed water quality guidelines. Should agreed standards not be met then the landform can be redesigned and the simulations re-run. This process can be repeated until agreed standards are predicted to be met (Figure 1).

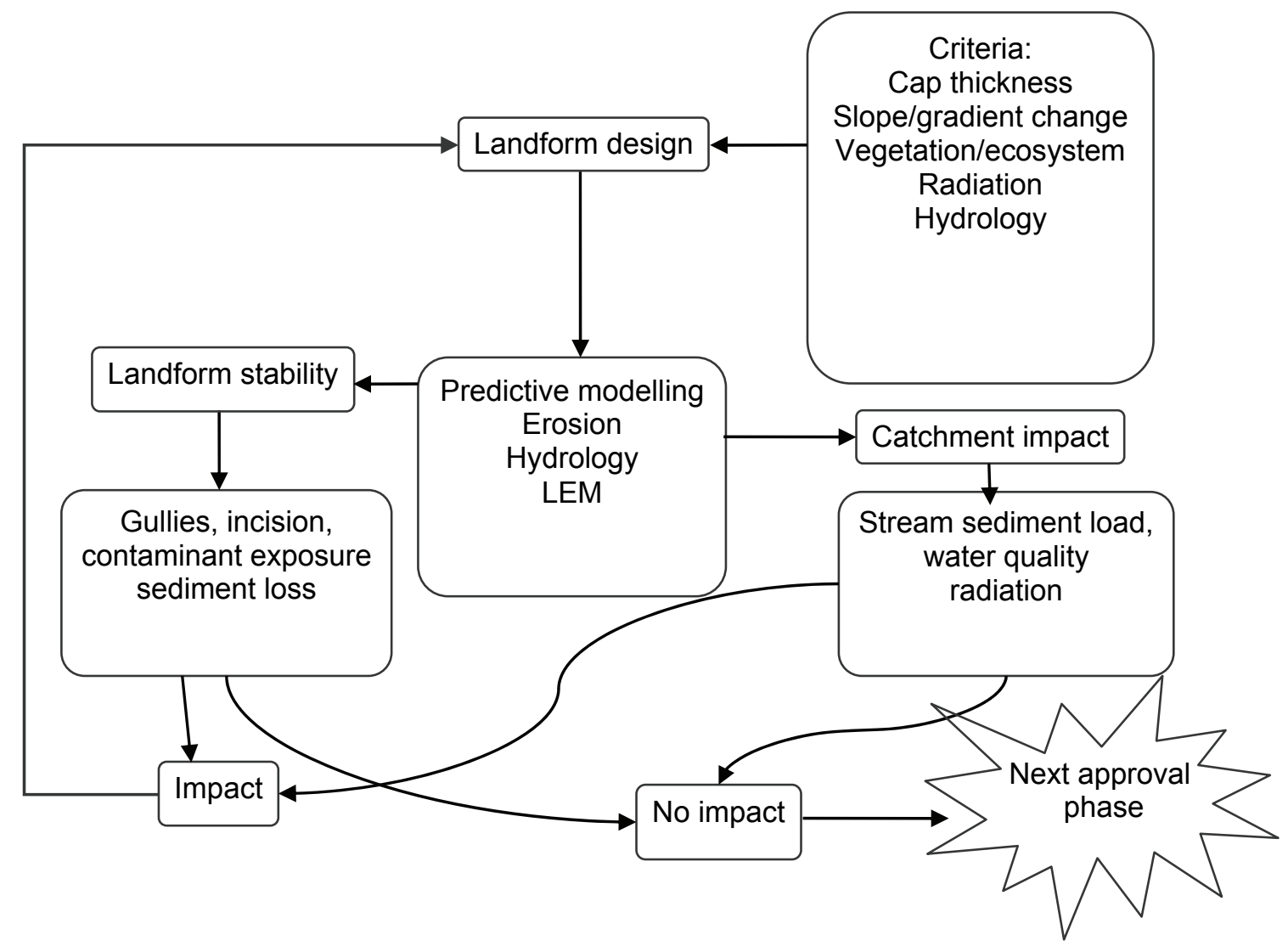

Figure 1 Flow chart showing conceptualisation of the iterative landform design process

Three-dimensional landscape evolution models (LEM) such as Siberia have considerable advantages over empirical based models, as they determine slope length and angle, can simulate both erosion and deposition 
and dynamically adjust the landscape to account for erosion and deposition, producing a dynamic representation of slope and angle over the duration of the simulation. Until recently, only Siberia was being used to simulate the long-term behaviour of the proposed Energy Resources of Australia (ERA) Ranger Mine rehabilitated landform (Lowry et al., 2006). Siberia simulations use an average area-discharge relationship for a whole wet season and do not use the time series hydrology of a single rainfall event or series of events. Consequently, the average long-term erosion assessments conducted to date have not implicitly addressed the impact of an extreme rainfall event or a series of events comprising an extreme wet season. For the purposes of this study, the definition of extreme rainfall event as described in CSIRO (2007) has been adopted. This defines extreme rainfall events as those that represent the highest one per cent of precipitation events that have been recorded within the area of interest - in this case, the top end of the Northern Territory.

Climate change concerns have strengthened the need to understand the effect of extreme rainfall events on the landform to assess possible impacts of large sediment influx to surrounding streams. For example any changes in the magnitude and frequency of extreme rainfall events could have a significant impact on the stability of mine rehabilitation works. To address this issue the CAESAR LEM (Coulthard, 2001) is currently being trialled. A particular strength of CAESAR is that it can use input data from discrete rainfall and runoff events, enabling the effect of extreme rainfall events on landform stability to be simulated. Hancock et al. (2009) have described the application of both the CAESAR and Siberia models to a study site in Tin Camp Creek, Northern Territory. Here we evaluate the suitability of CAESAR for assessing the stability of rehabilitated landforms at the Ranger mine and the effects of extreme rainfall events on landform erosion.

\section{CAESAR}

CAESAR is a cellular landscape and river reach evolution model. Inputs are a DEM of a river catchment or reach, water and sediment fluxes, and time series rainfall data. For each grid cell in the DEM, further values are stored representing hydrological parameters, grain size, water discharge, vegetation levels, etc. Then for every model iteration, these are altered according to: hydraulic routing; fluvial erosion and deposition; and slope processes. A modification of the hydrological model TOPMODEL (Beven and Kirky, 1979) is used to generate a combined surface and subsurface discharge from rainfall data.

For hydraulic routing the model takes the discharge from an in-built hydrological model and then routes this to neighbouring cells. A depth is calculated for this discharge, which allows flow to be routed over, as well as around, obstacles. After flow depths and inundation locations for the reach/catchment are determined, fluvial erosion is calculated using nine different grain sizes embedded within a series of active layers. This allows bed armouring effects and the development of a limited stratigraphy. Soil creep is calculated and mass movement (landslides) occur when a critical slope threshold is exceeded based on slope alone and a diffusivity coefficient. A simple growth model simulates vegetation growth, where undisturbed by floods, which inhibits surface erosion. Growth rates are linear, and when fully grown the vegetation provides resistance to flows up to a shear stress of $50 \mathrm{~Pa}$ above which it is removed and the exposed sediment below can be eroded. For a full description of the CAESAR model see Coulthard et al. (2002) and Van de Wiel et al. (2007).

CAESAR can be used to simulate the impact of extreme rainfall events, since time series data for actual or simulated rainfall events can be used as input. This is a critical model attribute as Ranger Mine rehabilitation must contain radioactive material for long time periods and it is likely that one or more very extreme rainfall events will occur during that time. Extreme event testing of the proposed rehabilitated landform has assumed greater importance given the possibility of increases in frequency and intensity of rainfall resulting from climate change.

\section{Applying CAESAR to the ERA Ranger Mine, Northern Territory}

The ERA Ranger Mine is currently the largest producer of uranium oxide in Australia. The Ranger Project Area (RPA) is surrounded by, but excised from, the World Heritage listed Kakadu National Park in the Northern Territory of Australia (Figure 2). The mine site is located on the left bank of Magela Creek and erosion products from the mine may impact the three small catchments surrounding the mine: Corridor (to the southeast), Georgetown (to the east) and Coonjimba Creeks (to the northwest), and the large catchment 
of Gulungul Creek to the west of the mine. Downstream, Magela Creek debouches into the East Alligator River through a broad expanse of floodplain and wetlands listed as 'Wetlands of International Importance' under the Ramsar Convention. The RPA, which lies in the wet-dry tropics, receives high-intensity storms and tropical monsoons between October and April with little rain falling for the remainder of the year.

The Ranger Mine, operational since 1981, plans to continue uranium concentrate production until 2020 (Johnston and Needham, 1999; Hollingsworth and Lowry, 2005). Pit 1 (see Figure 2) is now used for tailings deposition, supplementing the existing above-grade tailing storage facility. At the completion of mining, tailings from the above-grade facility will be transferred to Pit 3, which, along with Pit 1 , will be capped. The above-grade waste rock dumps will be rehabilitated.

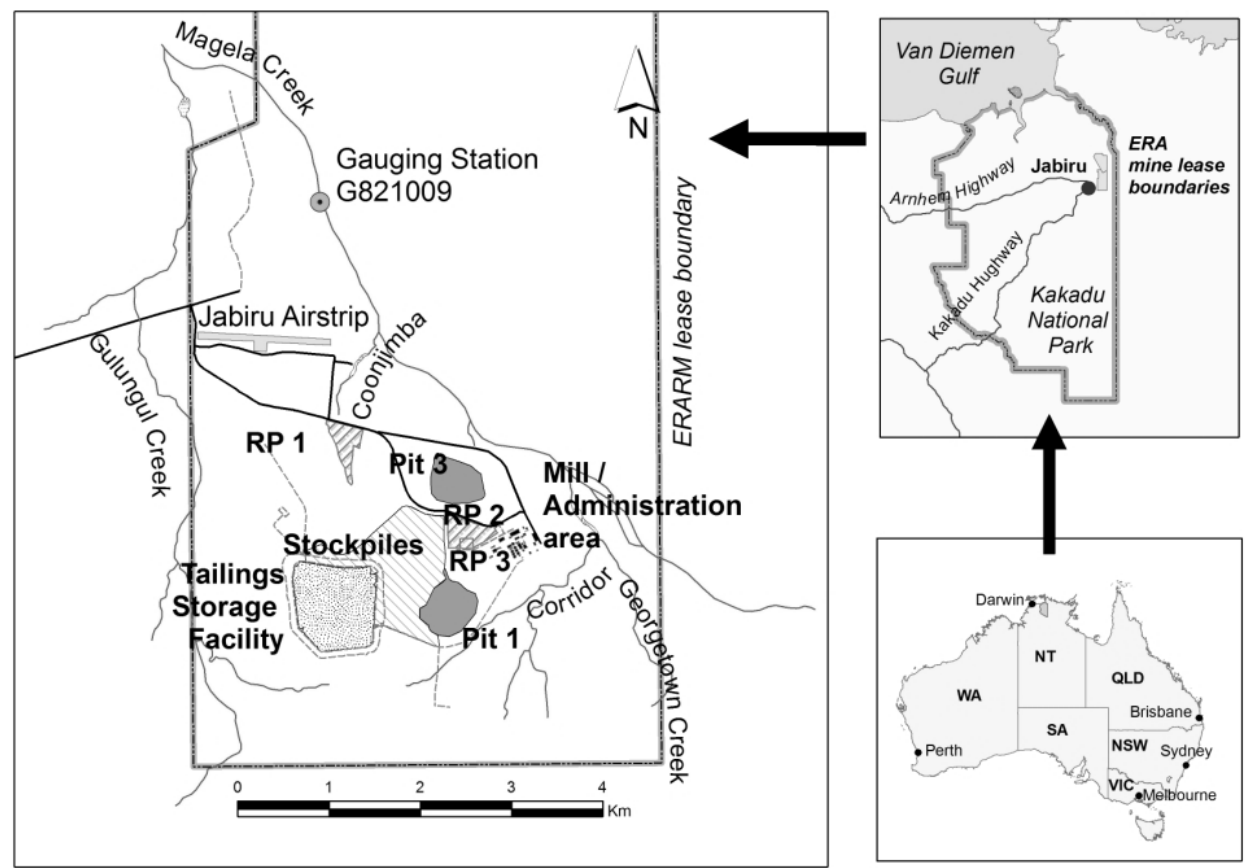

Figure 2 Location and layout of the Ranger Mine

In this study, the CAESAR model was applied to the catchment of the proposed rehabilitation landform which drains what is now the tailings dam (Figure 3). A $25 \mathrm{~m}$ resolution DEM of the proposed rehabilitated landform was supplied by ERA. The DEM of the proposed landform was hydrologically corrected and pitfilled and catchment boundaries and drainage lines defined using ESRI ArcGIS ${ }^{\mathrm{TM}}$ software with the ArcHydro ${ }^{\mathrm{TM}}$ extension.

In the simulation, the modelled catchment has an area of 921 ha, and a mean slope of 1.9 per cent. Unlike Siberia, CAESAR can not presently simulate the effect of different areas of surface treatment on a landform such as vegetation and ripping, hence intial simulations used only the proposed tailings dam sub-catchment (TDC). This catchment flows into Magela Creek (Figures 2 and 3) draining the rehabilitated tailings dam footprint through a channel between the capped Pit 1 and capped Pit 3. It is the largest catchment with uniform surface treatment on the proposed rehabilitated site. 


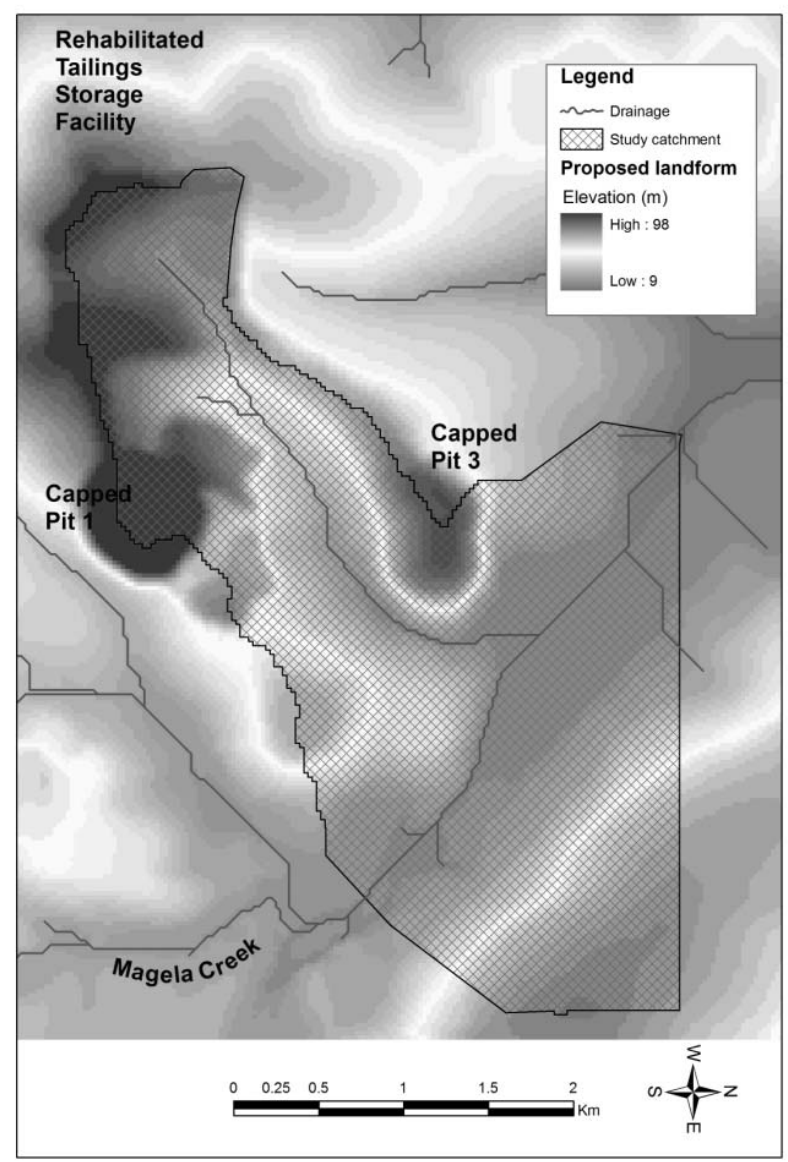

\section{Figure 3 Location of catchment being modelled}

\subsection{Landform simulations}

\subsubsection{Data sources}

The main data inputs required for CAESAR are rainfall data $(\mathrm{mm} / \mathrm{hr})$ and soil particle size distribution data. At Jabiru airport there were 21 years of complete annual rainfall intensity data, i.e. no gaps in the annual dataset, recorded in the period between 1972 and 2006. The one hour rainfall totals during these 21 years were used as input into the model. It is recognised that a finer temporal resolution of rainfall data, such as those collected at six minute intervals for rainfall pluviographs may better capture the dynamics of runoff and erosion. The ability to incorporate and model data at this resolution in CAESAR is an area of future possible research. However, this would likely have to be done on an event-specific basis, given the high computing requirements, and time required to model data at this temporal resolution. To simulate an extreme rainfall event the rainfall record for 2006-2007 was used. During late February and early March 2007 a period of exceptionally heavy rainfall occurred throughout the entire Magela Creek system as a result of a monsoon trough that extended across the top end of the Northern Territory. Approximately $785 \mathrm{~mm}$ of rainfall occurred over a three day period between 1700 hours on 27 February and 1700 hours on 2 March 2007 at Jabiru airport. This was the largest recorded three day rainfall in the top end. While rain fell almost continuously during this 72 hour period, four very intense rainfall episodes are recogniseable (Figure 4). The most intense period of rainfall occurred during the morning of 1 March 2007 where maximum rainfall intensities exceeded a 1-in-100 year storm event for durations between six and 72 hours. The resulting flood levels were the highest recorded in the Magela Creek catchment since 1971. 


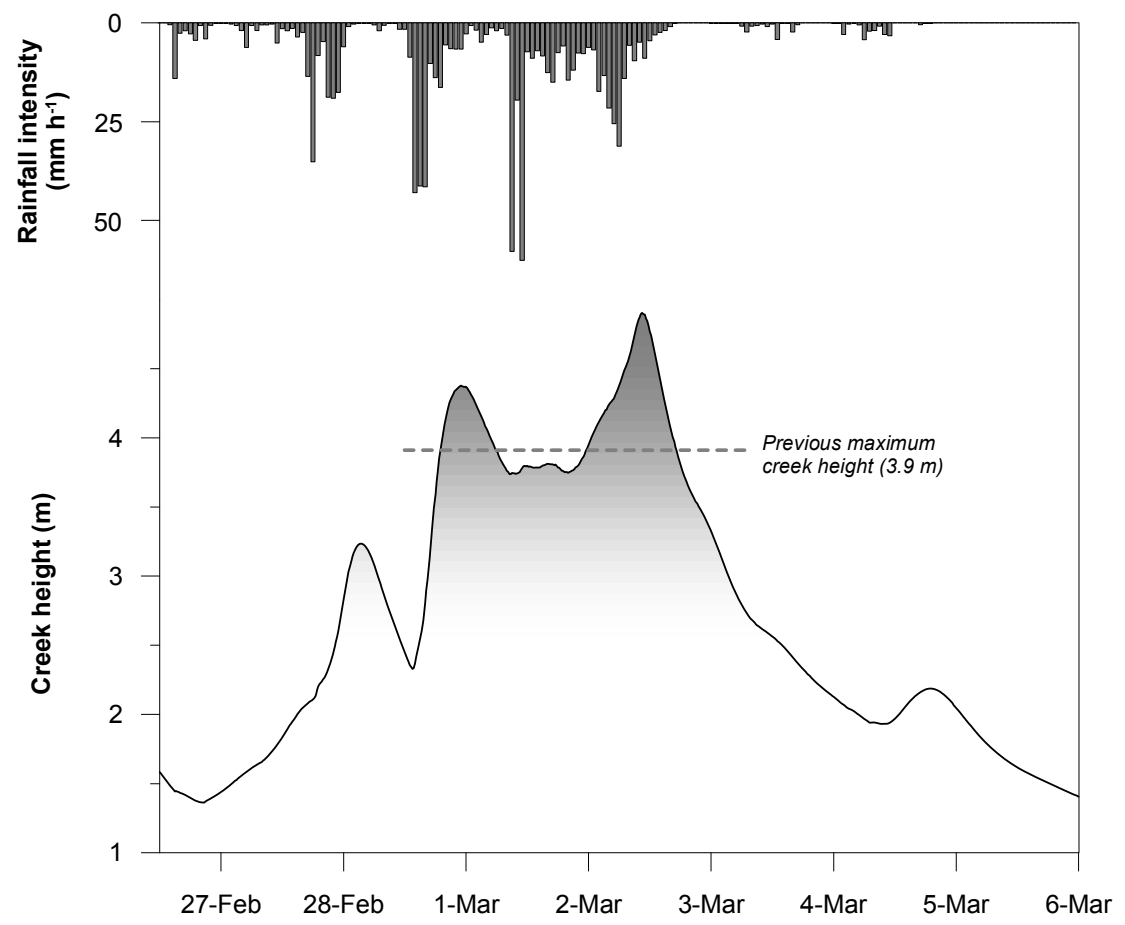

Figure 4 Hourly rainfall data collected at Jabiru airport during the flood event. The flood height at station G8210028, upstream of the mine along the Magela Creek is also shown

Total discharge in the main Magela Creek channel during the three day period between 1200 hours on 28 February and 1200 hours on 3 March 2007 was greater than the mean annual discharge. Peak flood height along the main channel was 25 per cent higher than the previous maximum recorded flood height on 4 February 1980. The corresponding peak discharges along the main channel were approximately eight times the mean annual flood discharge and more than double the 1-in-100 year flood event discharge.

\subsubsection{Model calibration}

As mentioned previously, primary measured data inputs are DEM, rainfall and particle size distribution. These can not be changed. Internal model parameters that can be varied are those such as initial number of scans, creep rate, suspended sediment size, minimum discharge depth, slope threshold, shear stress, and vegetation growth (Coulthard et al., 2003). Values for these specific internal parameters are not known for the waste rock which comprises the Ranger landform. Therefore a sensitivity analysis was conducted by progressively adjusting one of the internal parameter values, while holding the others constant, to assess the effect.

Simulations were run using the Jabiru rainfall record; surface material size distributions for Ranger waste rock (Evans and Loch, 1996); Magela Creek discharge (Q) data at gauging station G8210009 and estimated sediment discharge (Qs) for Magela Creek based on continuous turbidity data; and stream sediment size distributions of Roberts (1991). The Magela Q and Qs were used as inputs into Magela Creek at the upstream boundary of the DEM to simulate throughflow and backflow effects in the Magela Creek reach adjacent to the study catchment and how these effects may impact on transport and deposition of sediment leaving the study catchment. The simulations were conducted using a vegetation growth rate of 0.6 years - that is, the vegetation communities were assumed to reach maturity after a period of 0.6 year. For the purposes of this study, the vegetation community value was based on the growth rate of speargrass (Sorghum intrans) (Saynor and Evans, 2001). This meant that in the simulation, early rains would initially fall on bare waste rock but after a period of 0.6 years, vegetation, i.e. speargrass, would reach maturity and remain that way for the rest of the simulated period. It is recognised that this value does not represent a mature vegetation community with woody trees and groundcover. Consequently, further work is required to better reflect the succession to a mature vegetation community on a rehabilitated landform. 
The sensitivity runs were continued, progressively changing parameters values until a denudation rate of approximately $0.04 \mathrm{mmy}^{-1}$, similar to that measured for waste rock in the region, was obtained. By this process the values of the internal parameter values were optimised through iteration and back-fitting to the known denudation rate. Some of the final fitted parameter values varied quite a bit from default values used in the model. However, it must be recognised in this context that waste rock is a very different substrate type to that for which the model was originally developed, i.e. braided rivers and natural lanform catchments. Notwithstanding this, the optimised parameter values were still reasonable and mostly within the same order of magnitude as the default values. This process gave us confidence that the model would provide reasonable, i.e. close to, measured erosion rates for waste rock, whereas using the default values would have yielded vastly different erosion rates. This iterative process for parameter optimisation is an accepted process for calibrating both erosion and hydrology numerical models, where not all model variables can be physically measured.

\subsubsection{Simulation scenarios}

Once the internal parameter values were optimised, three simulations were run:

1. A 21 year period using the observed hourly rainfall record and daily Magela Q and Qs for complete years between 1972 and 2006.

2. A 21 year period as above with the 2006-07 time series for Q and Qs data inserted after 10 years to assess the impact of an extreme event after the landform has reached equilibrium.

3. A 21 year period using the 2006-07 rainfall year to replace the first year of the 1972-06 data series used in run 1 above. This was to simulate the effects of an extreme event on the landform in the wet season immediately after rehabilitation.

These simulations allowed us to test how the very large event in March 2007 affected denudation rates compared to the denudation rates under the average Jabiru rainfall.

\subsection{Results}

Annual denudation rates for each simulation are shown in Figure 5. The simulations show that there is a high level of sediment loss in the initial years as the new landform finds equilibrium. This is the phase of catchment conditioning simulated by CAESAR as fine sediment is removed from the catchment, drainage lines are incised, particle size distribution of the surface material is adjusted and vegetation grows, leaving coarser material in the thalweg of drainage lines.

Simulations show that the catchment is conditioned in about five years. Similar observations of catchment conditioning or surface armouring have been observed in field erosion studies at mine sites and for natural terrains in the Alligator Rivers Region (Moliere et al., 2002). After the phase of catchment conditioning all three simulations have similar outputs with respect to denudation rates which oscillate between positive (erosion) and negative (deposition) with annual medians of $0.01-0.07 \mathrm{mmy}^{-1}$, and annual averages of $0.17-0.21 \mathrm{mmy}^{-1}$, and ranges of $-0.08-0.94 \mathrm{mmy}^{-1}$. Negative rates indicate that Magela sediment input from upstream is greater than that exported and that deposition has occurred within the catchment. 

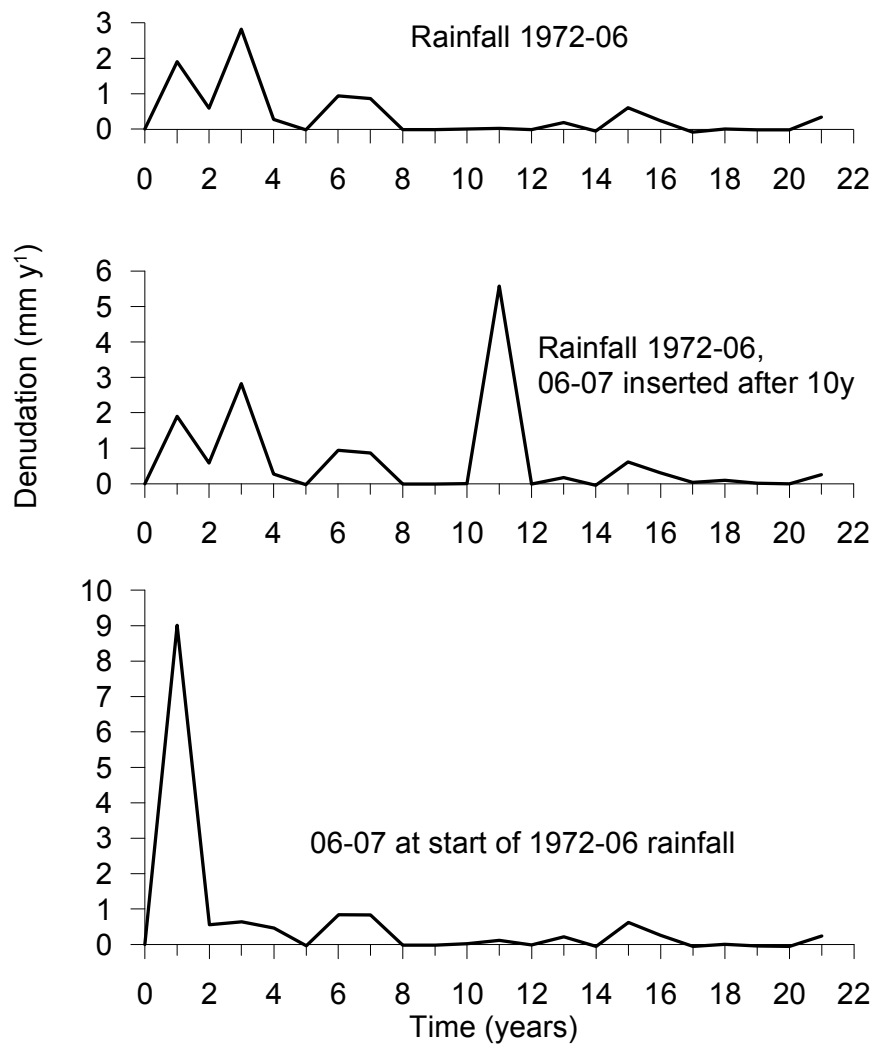

\section{Figure 5 Denudation rates of the TDC and Magela reach simulated using CAESAR with various rainfall inputs}

Previous studies in the area give a range of denudation rates for waste rock of $-2-7 \mathrm{mmy}^{-1}$ with a median of $0.04 \mathrm{mmy}^{-1}$ and for natural areas, denudation rates of $-1.25-1.25 \mathrm{mmy}^{-1}$ with a median of $0.018 \mathrm{mmy}^{-1}$ (Erskine and Saynor, 2000). The simulated denudation rates, after the initial perturbations, compare well with published erosion rates. This is expected, since input parameter values for these simulations were calibrated to the range of known erosion rates. However, the aim of the calibration was to get the model producing erosion rates that were reasonable by fitting parameter values against known outputs. This gives us confidence that the average physical processes in the catchment are adequately simulated by the model. These processes include flow path location, erosion and deposition location and sediment transport through the catchment and subsequent dispersion in Magela Creek. The initial large oscillations are also to be expected as any system in disequilibrium usually oscillates to the steady state condition. However, further research is required to confirm the magnitude of these oscillations. With the confidence that the model is simulating catchment processes appropriately we could then assess how the March 2007 event affected denudation rate.

Initial application of the 2006-07 rainfall time series (Figure 5, simulation three) is sufficient to flush all of the mobile sediment from the catchment in the first year giving a denudation rate of $9 \mathrm{mmy}^{-1}$, with little further conditioning taking place in the following years. If, instead, this extreme event occurs after ten years (Figure 5, simulation two), a large pulse of sediment is exported with a denudation rate of $5.58 \mathrm{mmy}^{-1}$ with erosion rates returning to normal after a year.

Examining the denudation rates in Figure 5 reveals more interesting behaviour. For all three runs, aside from the time at which the extreme events is inserted, all the other peaks relating to events are largely the same. For runs one and two they are identical apart from where the peak is introduced. On run three there appears to be an exhaustion effect, so the peak in year three is reduced considerably. This behaviour implies that once the system is stabilised, with respect to settlement and initial sediment removal, the subsequent response of the catchment to all the other events is not modified by the one large event. In the simulation, the vegetation (speargrass) growth rates are linear, and when fully grown the vegetation provides resistance to flows up to a shear stress of $50 \mathrm{~Pa}$ above which it is removed and the exposed sediment below can be eroded. 
It might be expected that the system would be significantly perturbed by such a large event and take some years to recover with impacts in subsequent years, but this is not shown here.

These simulations do not account for the different morphologies, sand bed channel or surface condition, vegetation abundance of the riparian zone and adjacent woodlands or variation in particle size distribution between the waste rock and the Magela channel. However, the results indicate that CAESAR has very good potential for simulating the effects of extreme events on landform stability and sediment export from the mine site to natural areas of the catchment. The CAESAR interface allows the user to visualise how a sediment pulse moves through a system. The series in Figure 6 shows a pulse moving along the channel between Pits 1 and 3, entering the main Magela channel, and then being dispersed downstream along the channel.

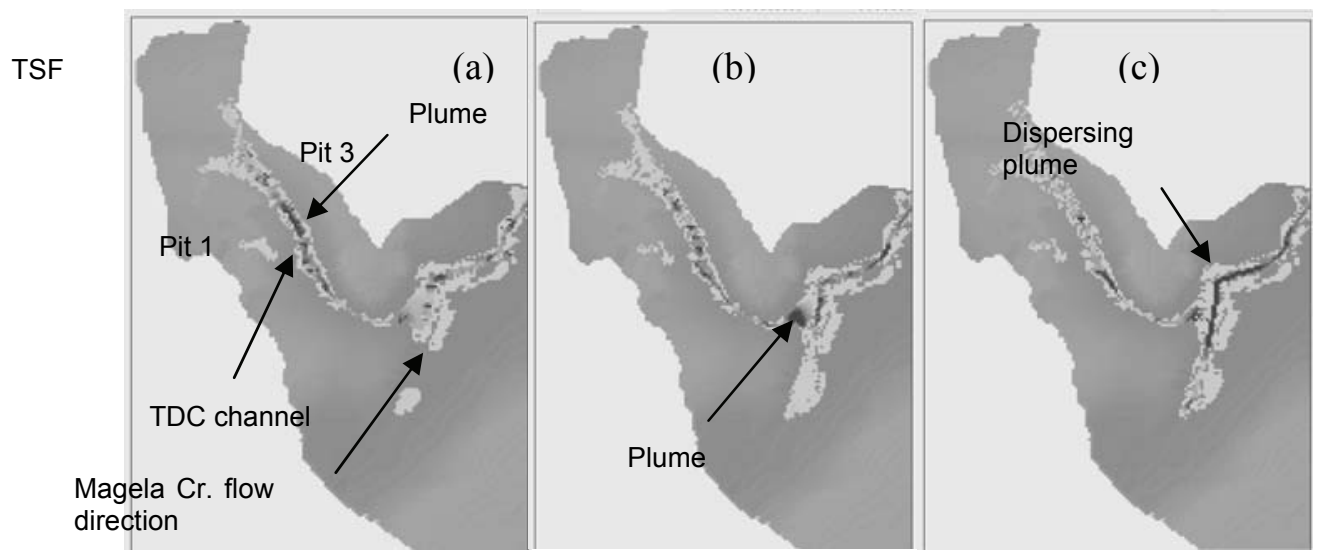

Figure 6 CAESAR output during the very large March 2007 event over a period of approximately 72 hours showing (a) sediment pulse moving through the TDC; (b) entering Magela Creek; and (c) being dispersed along the channel to the outlet

\section{$4 \quad$ Summary and conclusions}

Soil erosion and landscape evolution models offer the ability to better understand erosion and hillslope processes that will occur on rehabilitated mine landforms and allow better design and management to reduce the potential impact of these processes. Numerical modelling is the only quantitative method by which projections can be made about landuse and climate change variability on catchment processes. It is important that these models and modelling procedures be evaluated, and that model results be validated against field data.

As discussed in the results, the model simulation results reported here compare well with independent field data determined for the region. A major advantage of CAESAR compared to other LEM models, such as Siberia, is that it has much simpler input requirements and is able to utilise data that may have already been collected for other purposes, e.g. hourly rainfall and particle size distribution. In comparison, before Siberia can be run, it is necessary to calibrate the area-discharge and sediment transport equations. However, while outputs from CAESAR may be produced hourly, a considerable time is required to run simulations of long time periods due to the computer processor power required.

CAESAR has not yet been fully tested for this application of assessing the stability of post-mining landforms and a better understanding of the catchment conditioning phase and how this relates to reality is required. In particular, the capability to simulate variation in surface treatments across a catchment is being developed as this is required before this model can adequately simulate the behaviour of a rehabilitated mine site in the context of its surroundings.

\section{References}

Beven, K.J. and Kirkby, M.J. (1979) A physically based variable contributing-area model of catchment hydrology, Hydrological Science Bulletin, Vol. 24(1), pp. 43-69.

Bureau of Meteorology (1999) Hydrometeorological analyses relevant to Jabiluka, Supervising Scientist Report 140, Supervising Scientist, Canberra, $25 \mathrm{p}$. 
Commonwealth Scientific and Industrial Research Organisation (CSIRO) (2007) Climate Change in Australia: Technical Report 2007,CSIRO, 148 p.

Coulthard, T.J. (2001) Landscape evolution models: a software review, Hydrological Processes 15, pp. $165-173$.

Coulthard, T.J., Dennis, I. and Foster, G. (2003) Instructions for using Visual CAESAR/TRACER, 1 December 2003, unpublished, $19 \mathrm{p}$.

Coulthard, T.J., Macklin, M.G. and Kirkby, M.J. (2002) Simulating upland river catchment and alluvial fan evolution, Earth Surface Processes and Landforms, Vol. 27, pp. 269-288.

Erskine, W.D. and Saynor, M.J. (2000) Assessment of the off-site geomorphic impacts of uranium mining on Magela Creek, Northern Territory, Australia, Supervising Scientist Report 156, Supervising Scientist, Darwin, NT, 59 p.

Evans, K.G. (2000) Methods for assessing mine site rehabilitation design for erosion impact, Australian Journal of Soil Research, Vol. 38(2), pp. 231-248.

Evans, K.G. and Loch, R.J. (1996) Using the RUSLE to identify factors controlling erosion of mine soils, Land Degradation and Development, Vol. 7, pp. 267-277.

Flanagan, D.C. and Livingston, S.J. (1995) Water Erosion Prediction Project (WEPP) version 95.7 User Summary, National Soil Erosion Reseach Laboratory Report 11, 131 p.

Hancock, G.R., Lowry, J.B.C., Coulthard, T.J., Evans, K.G. and Moliere, D.R. (2009) A catchment scale evaluation of the Siberia and CAESAR landscape evolution models, Earth Surface Process and Landforms - in press.

Hollingsworth, I. and Lowry, J. (2005) Landscape reconstruction at Ranger mine, In Proceedings of the North Australian Remote Sensing and GIS Conference, Darwin, Australia, Applications in Tropical Spatial Science (CD-ROM only).

Johnston, A. and Needham, S. (1999) Protection of the environment near the Ranger uranium mine, Supervising Scientist Report 139, Supervising Scientist, Canberra, 33 p.

Laflen, J.M., Elliot, W.J., Simanton, J.R., Holzhey, C.S. and Kohl, K.D. (1991) WEPP soil erodibility experiments for rangeland and cropland soils, Journal of Soil and Water Conservation, pp. 34-39.

Loch, R.J., Connolly, R.D. and Littleboy, M. (2000) Using rainfall simulation to guide planning and management of rehabilitated areas: Part 2, Computer simulations using parameters from rainfall simulation, Land Degradration and Development, Vol. 11(3), pp. 241-255.

Lowry, J.B.C., Evans, K.G., Moliere, D.R. and Hollingsworth, I. (2006) Assessing landscape reconstruction at the Ranger mine using landform evolution modelling, In Proceedings of the First International Seminar on Mine Closure, Mine Closure 2006, A.B. Fourie, M. Tibbett (eds), 13-15 September 2006, Perth, Australia, Australian Centre for Geomechanics, Perth, pp. 577-586.

Moliere, D.R., Evans, K.G., Willgoose, G.R. and Saynor, M.J. (2002) Temporal trends in erosion and hydrology for a post-mining landform at Ranger Mine, Northern Territory, Supervising Scientist Report 165, Supervising Scientist, Darwin, Australia, 118 p.

Onstad, C.A. and Foster, G.R. (1975) Erosion modelling on a watershed, Transactions of the American Society of Agricultural Engineers, Vol. 26, pp. 1102-1104.

Renard, K.G., Laflen, J.M., Foster, G.R. and McCool, D.K. (1994) The Revised Universal Soil Loss Equation, In Soil Erosion Research Methods, R. Lal, (ed), Second Edition, Soil and Water Conservation Society, Ankeny, USA, pp. $105-124$.

Riley, S.M. (1994) Approaches to estimating the erosional stability of the Nabarlek tailings pit cover, In Proceedings of the AusIMM Annual Conference, Darwin 5-9 August 1994, AusIMM, Melbourne, pp. 415-421.

Roberts, R.G. (1991) Sediment budgets and Quaternary history of the Magela Creek catchment, tropical northern Australia, PhD Thesis, Department of Geography, University of Wollongong, 569 p.

Saynor, M.J. and Evans, K.G. (2001) Sediment loss from a waste rock dump, ERA Ranger Mine, northern Australia, Australian Geographical Studies, Vol. 39(1), pp. 34-51.

Van De Wiel, M.J., Coulthard, T.J., Lewin, J. and Macklin, M.G. (2007) Embedding reach-scale fluvial dynamics within the CAESAR cellular automaton landscape evolution model. Geomorphology, Volume 90(3-4), pp. 283-301.

Willgoose, G.R., Bras, R.L. and Rodriguez-Iturbe, I. (1989) A physically based channel network and catchment evolution model, TR 322, Ralph M. Parsons Laboratory, Department of Civil Engineering, MIT, Boston, USA, $464 \mathrm{p}$.

Wischmeier, W.H. and Smith, D.D. (1978) Predicting rainfall erosion losses - a guide to conservation planning, Agriculture Handbook No. 537.2, US Department of Agriculture, 85 p. 